\title{
Political Change, Citizenship Rights, and the Welfare State
}

\author{
By MAYER N. ZALD
}

\begin{abstract}
Changes in political structure, coalitions, and ideology provide the context in which specific policies and programs are adopted and, once adopted, expanded or trimmed. This article assays a portrait of American politics in the early 1980 s and the major trends relevant to welfare choice. It is shown that voters have loosened their ties to parties even while the parties have strengthened their organizational capacities. Although there is little evidence that American voters wish to dismantle the welfare state, the growing strength of the Republican party as a campaign vehicle and the greater party competition among parties in all regions suggest that Republican congressional and senatorial strength will be stronger than in the fifties and sixties. Moreover, trends to expand citizen rights that bear on welfare issues may have been arrested. Issue heterogeneity, the dissolution of older political coalitions, and economic trends suggest that broad welfare state issues will be on the back burner, though there is no evidence that broad-based programs face significant cutbacks.
\end{abstract}

Mayer N. Zald received his B.A. and Ph.D. from the University of Michigan and his M.A. from the University of Hawaii. He was on the faculty of the University of Chicago (1960-64) and Vanderbilt (1964-77) before returning to Michigan, where he is chairman of the Department of Sociology. He has published numerous books and articles on complex organizations, social movements, and the sociology of social welfare. 
$\mathrm{T}$ HE United States has been a welfare state laggard. Definitions of the welfare state include retirement pensions, unemployment subsidies, universal medical care services or payments, minimum incomes for families, and services for children and mothers as core components of the welfare state. Compared to many economically developed countries, the United States was slow to universalize its pension system and to provide widespread access to medical care. To this day it does not have a minimum income program for families. The United States has been a leader in the provision of mass public educational opportunities; however, experts on the welfare state often do not consider educational provisions a core program of the welfare state. Those provisions can be supported by states with little commitment to the provision of minimum welfare needs for dependent populations. '

Although the United States has been a welfare state laggard, by the end of the 1960s the political process resulted in the adoption of a number of programs that substantially closed the gap between it and other advanced industrial nations. ${ }^{2}$ The adoption of the Supplemental Security Income (SSI) program, which universalized the retirement system, and the adoption of Medicare and Medicaid, providing medical insurance and service to the elderly and the poor, were major additions that brought us

1. Harold L. Wilensky, The Welfare State and Equality: Structural and Ideological Roots of Public Expenditures (Berkeley: University of California Press, 1975), pp. 3-7.

2. The political-legislative history of the adoption of welfare state policies in the 1960s is told in James L. Sundquist, Politics and Policy: The Eisenhower. Kennedy, and Johnson Years (Washington, DC: Brookings Institution, 1968). closer to our European peers. Sundquist shows how the welfare state legislative agenda of the 1960 s was a continuation of the New Deal prepared by liberal policy experts, inside and outside of Congress. It came to fruition in the context of the civil rights movement and liberal Democratic presidencies.

Yet, by the late 1970 s and 1980s the political trends had changed. Faced with high rates of inflation, recession, budget deficits, a rapid growth in social expenditures, and perceived military weaknesses, the Carter administration began-and the Reagan administration has continued - to attempt to rein in the welfare state.

Is this direction inevitable? What are the prospects for rekindling the welfare state? Are there underlying trends in political ideology, in socioeconomic political coalitions, in political structures, that imply one direction or another for the future of the welfare state? Has the New Deal coalition broken up? Is the party system breaking up? If so, what are the implications for welfare programs?

Here I ruminate on the changing tides and structures of politics in the United States. Commentators on the American political scene have identified a number of trends in American politics that, if confirmed, might have strong implications for welfare policies and choices: a weakening of party structure, the growth of media politics, changing ideology, and strong federal court supports for transforming privileges into program entitlements. Each of these, if true, has implications for program choice and the overall directions of the welfare state. My review leads me to the conclusion that some presumed trends are shakier than might be expected. Moreover, the political trends and changes that are 
operative have mixed implications for the welfare state.

I examine the implications of political change for welfare policy under a set of underlying assumptions about the socioeconomic constraints facing the United States. Those constraints are treated in greater detail elsewhere in this issue of The Annals, ${ }^{3}$ but let us make them explicit here. First, there is little doubt that the aging of the population will create pressures for increases in the funding base of public retirement programs-social security, SSI-and health programs for the elderly. Moreover, since social security and other programs were never based upon pure annuityinsurance principles that tied returns to a cohort solely to the moneys received from, and invested for, the cohort, the tax base through which the programs are funded is heavily dependent upon the state of the economy and the willingness of Congress and the younger generations to fund the increasing costs of those programs.

Second, without substantial economic growth to fuel expanded tax revenues, or without major declines in expenditures in other sectors, there will be continuing pressures to constrain the expansion of health and welfare expenditures and to restructure programs whose costs are increasing rapidly. By 1984 serious attempts had been made to restructure the funding of social security and to at least trim its benefits, and hospital reimbursement formulas had been changed in order to cut into the galloping expansion of health care costs.

3. See W. Allen Spivey, "Problems and Paradoxes in Economic and Social Policies of Modern Welfare States, "this issue of The Annals of the American Academy of Political and Social Science; William C. Birdsall and John L. Hankins, "The Future of Social Security," ibid.
Third, pressures to rein in the welfare state could be resisted and the welfare state expanded if the American people were willing to expand the tax base and raise tax levels. By comparative standards, Americans are not overtaxed. Compared to most Western European countries the proportion of national income that is channeled to the government is relatively reasonable. ${ }^{4}$

However, the issue is not how American tax rates compare to Sweden or to Germany but what the population is willing to bear in the way of taxes-how much the citizenry and politicians believe they should be taxed. And there is little likelihood of anything besides marginal increases in rates of American taxation over the next decade or so. The mid-1970s were characterized by tax revolts in California that substantially lowered taxes on real estate. While some states, such as Ohio and Michigan, raised taxes to cope with budget deficits in the recession years of the early 1980s, there is no evidence that Americans are prepared to entertain large increments in their tax expenditures in order to fund expanded welfare social programs.

Now, holding these assumptions in the background, what are some of the major trends in American political life that bear on policy preferences? Politicians must be elected, thus voter preferences and party leanings are of import. Is there a trend toward conservatism and do the parties differ in their conservative/liberal identifications? Parties aggregate preferences, thus party organization bears on how preferences are shaped by party structures. Can the Democrats outmobilize the Republi-

4. Public Expenditure Trends, OECD Studies in Resource Allocation, no. 5 (Paris: Organization for Economic Cooperation and Development, 1978). 
cans? Presidential politics and how presidents relate to Congress is of importance, thus changes in the presidency and in its interaction with Congress must be examined. Courts in interaction with bureaucracies and legislatures define the living constitution; they define rights and benefits and their distribution to the population, thus I must examine the trends in citizenship rights as channeled by the courts. Finally, overall trends in political integration, social movements, and issue generation in the larger society must be examined; for it is in these areas of political organization that some of the larger differences between the United States and Europe are found.

We will see that there are in fact conflicting trends within the United States. There is broad support for the continuing of basic social welfare programs, even though the growing strength of the Republican party, the decline in labor union support, and the fragmentation of the issue agenda dissolve support for major new initiatives.

\section{PARTY STRENGTHS}

AND ATTACHMENTS

Trends in voter attachments to parties and the correlates of those attachments tell us much about the possibilities of policy choice in a democracy. If voters are increasingly attached to parties, and the social bases of parties differ significantly, then we are at least partly on the way to predicting the direction of policy choice in America. Parties in office will attempt to represent the interests of the underlying class or group preferences of their supporters. On the other hand, if voters are weakly tied to parties, and if groups are not clearly identified with parties or do not see a link between their policy preferences and party stands, there may be increasing indeterminacy in the linkage between parties and voters. ${ }^{5}$

What do we know about trends in partisan attachment over the last several decades? First, it is widely recognized that the proportion of the population indentifying themselves as independents or weak partisans increased rapidly in the 1960s and 1970s. Once a minority, independents now outnumber Republicans substantially-five to three-and almost equal the number who claim to be Democrats. Moreover, independents vote less, are less aware of the position of candidates, and have less interest in politics.

It turns out, however, that there are subtle distinctions to be made in the meaning of the growth of independents. Surveys have asked not only whether respondents are Democrats, Republicans, or independents, but have also probed their leanings as independents or as party identifiers. Partisans or leaning independents-those who claim to be independents but also claim to have a preference-have greater knowledge of politics than plain independents. Indeed, leaning independents have greater knowledge of politics and vote more consistently than people who claim to be weakly identified with particular parties-the contrast here is between a weak partisan and a partisan independent. It would appear that although party attachment has declined, knowledgeability and interest have not de-

5. A comprehensive review of many of the issues raised in this section is found in Donald $R$. Kinder and David O. Sears, "Public Opinion and Political Action," in The Handbook of Social Psychology, 3rd ed., ed. Gardner Lindzey and Eliot Aronson (Cambridge, MA: Addison-Wesley, forthcoming). 
clined as much. It is the case that strong partisanship has declined by about a third since 1952. The rise of independent voting shows itself in one other indicator, the increase in split-ticket voting. Split-ticket voting between members of Congress and the president has increased substantially, from 15 percent in the 1950 s to over 25 percent in the 1970 s. Table 1 presents basic data about party attachment.

Although Democrats of all kinds continue to outnumber Republicans by a substantial margin, many more members of both parties are weakly attached. They do not have strong identifications, they split votes, and even if they do have strong identifications they are more likely to defect than they were in the 1950 s.
Not only have attachments to parties become more volatile, but participation in elections has declined. For instance, the percentage of eligible voters voting declined from 63 percent in 1960 to 53 percent in 1980; off-year congressional election voting declined from 45 percent in 1962 to 35 percent in $1978 .{ }^{6}$ Abramson and Aldridge attribute the decline to a lessening of party loyalty, which leads to less concern about electoral outcomes and to a perception that government is less able to respond effectively. It is clear that the decline in turnout and in partisanship is especially prominent among

6. Paul R. Abramson and John H. Aldrich, "The Decline of Electoral Participation in America," American Political Science Review, 76: 50252 (Sept. 1982).

TABLE 1

PARTY IDENTIFICATION IN SELECTED OFF-YEAR ELECTIONS

1954-82 (Percentage)

Question: Generally speaking, do you usually think of yourself as a Republican, a Democrat, an Independent, or what? [If Republican or Democrat] would you call yourself a strong Republican/ Democrat or a not very strong Republican/Democrat? [If independent or other] do you think of yourself as closer to the Republican or Democratic party?

\begin{tabular}{lrrrrr}
\hline $\begin{array}{l}\text { Respondents Identifying } \\
\text { Themselves as }\end{array}$ & 1954 & 1962 & 1970 & 1978 & 1982 \\
\hline Strong Democrats & 22 & 23 & 20 & 15 & 20 \\
Weak Democrats & 26 & 23 & 24 & 24 & 24 \\
$\quad$ Strong and weak Democrats, combined & 48 & 46 & 44 & 39 & 44 \\
Independent Democrats & 9 & 7 & 10 & 14 & 11 \\
Independent & 7 & 8 & 13 & 14 & 11 \\
Independent Republicans & 6 & 6 & 8 & 10 & 8 \\
Weak Republicans & 14 & 16 & 15 & 13 & 14 \\
Strong Republicans & 13 & 12 & 9 & 8 & 10 \\
Apolitical & 4 & 4 & 1 & 3 & 2 \\
\hline
\end{tabular}

SOURCE: "Party Identification in the United States, American National Election Studies Data, 1952-82," Table of the American National Election Studies, Center for Political Studies, University of Michigan. 
younger cohorts, although the older groups have also decreased their participation.

So far, I have discussed attachment to party without discussing the social bases of attachment and shifts in the social base. Have Catholics become less likely to vote Democratic? What about Jews? Has the attachment of issues to parties changed? Answers to these kinds of questions suggest some realignment in the social bases and ideological preferences of the population. In most economically developed countries there has been a correlation between class and leftist voting, the working classes voting for leftist parties. This relationship has been weakest in the United States, ${ }^{7}$ but other social markers, such as religion and region, have had strong correlations. In the past two decades, class as a predictor of voting in the United States, always weak, has declined even further, and so has religion. On the other hand, there has been some substantial group realignment.

The most penetrating analysis of group realignment is found in John Petrocik's recent study of party coalitions and issue realignment. ${ }^{8}$ He finds that there has not been a shift of any sizable proportion in the extent to which the voting population has become more conservative. Petrocik finds that of the changes accounting for Republican presidential victories in the 1970 s, less than one-third can be accounted for by the electorate becoming more conservative. What Petrocik does find is a rolling

7. Robert R. Alford, Party and Society: The Anglo-American Democracies (Chicago: Rand McNally, 1963).

8. John R. Petrocik, Party Coalitions: Realignments and the Decline of the New Deal Party System (Chicago: University of Chicago Press, 1981). realignment of groups in the extent to which they identify one party or another as conservative or liberal on domestic issues. The two issues that show cleanest realignment are, on the one hand, the identification of the Democratic party as clearly the one that supports policies more favorable to blacks, and on the other hand, southern conservative whites' belief that the Republican party supports more conservative policies on welfare-related issues. More than ever, the Republican party captures the conservative vote.

It is easy to forget that as late as 1932 most blacks saw the Republican party as their party, and that as late as the beginning of the 1960s conservative southern whites still were in the Democratic party. By the late 1970s blacks had moved almost completely into the Democratic column. At the same time upper- and middle-status southerners had become almost evenly split between Republican and Democratic attachments, and white working-class members had substantially lowered their attachment to the Democratic party. ${ }^{9}$ Thus on race and welfare issues the party linkage has become much more clearly focused.

Of course, these are not the only changes in party alignments that have occurred. For instance, upper-status northeastern whites are more likely to vote Democratic in 1980 than they were in the 1960s, while Jews, a small voting group, are slightly more likely to vote Republican in the 1980s than they were in the 1960s. But the most fundamental shift has been the growth of a two-party South, with the Republican party being

9. Norman H. Nie, Sidney Verba, and John R. Petrocik, The Changing American Voter (Cambridge, MA: Harvard University Press, 1979), pp. 221-23. 
the repository of more conservative policy preferences.

It is worth noting that a key media issue of the $1980 \mathrm{~s}$, the relation of women's vote to parties, did not surface as a voting predictor throughout the $1960 \mathrm{~s}$ and $1970 \mathrm{~s}$. Indeed, women and men voted so much alike in these decades that gender was not a predictor of party identification or of voting. Gender made so little difference in elections until 1984 that political scientists dropped it from statistical analysis.

The fact that the Republican party is more clearly identified today with conservative positions - especially those related to welfare-type issues - than it was in the 1960s, does not mean, however, that the Republican party will be opposed to all issues related to the welfare state. Some issues, such as changes in social security laws, cut too wide a swath across the electorate for the party to ignore constituent demands. It is likely that on broad-based, middle-class social welfare or welfare state issues, the positions of Democrats and Republicans will be much closer than they are on welfare state issues that relate to the very poor. Indeed, Lawrence Bobo has documented a backlash on civil rights militancy that can easily contribute to negative attitudes toward poor blacks and related welfare policies. ${ }^{10}$ Republicans and Democrats will be close together on social security and mortgage subsidies. They are more likely to split on Aid to Families with Dependent Children (AFDC) and infant nutrition programs.

Although there has been a growth in independent voting, and some party

10. Lawrence Bobo, "Racial Hegemony: Group Conflict, Prejudice, Ambivalence and the Paradox of American Racial Attitudes" (Ph.D. diss., University of Michigan, forthcoming), chap. 3. realignment related to race and welfare, my discussion ignores another important dimension of party politics--the extent to which domestic party politics keys on one or two issues, as contrasted with confronting a multitude of issues. It is too easy to forget that the Roosevelt era and the strong polarization of politics along class- and welfare-related issues was a new phenomenon in American politics, at least to the extent that a pure class issue dominated the party images and polarization.

Everett Ladd and Charles Hadley argue that in fact the breakup of the New Deal coalition is a return to a more normal style of American party constellation. ${ }^{11}$ The New Deal coalition has changed, not only because of the shift of status groups-ironically enough, the dropping of the southern part of the New Deal coalition lowers Democratic dominance in the political process at the same time that it increases the clarity of party positions-but also as result of a more complicated issue-ideological agenda. Acid rain, environment, gay rights, the new cultural agenda, family issues, women's rights, pro-choice/prolife are issues unheard of in the 1950s. The new political agenda on domestic issues is not as easily seen as a left/right, socialist/capitalist, or social democrat/ capitalist split. The complexity of that new agenda makes it much more difficult to see a singular pattern of programmatic support for welfare state expansion, as could be seen in the 1950s or early 1960s. It is quite possible for capital and labor to align on one side on some environmental issues, and Repub-

11. Everett Carll Ladd, Jr., and Charles D. Hadley, Transformation of the American Party System: Political Coalitions from the New Deal to the 1970s (New York: W. W. Norton, 1975), pp. 332-35. 
lican and New Left environmentalists to be on the other side. Different issues, such as those related to family policy, women's rights, and abortions, split traditional alliances-or unite traditional adversaries-once again. Catholic supporters of Democratic party policies may align with Protestant fundamentalist Republicans on abortion policies. Finally, some issues, such as the rapid increase in medical costs and a perception that welfare-related spending is increasing, lead to a search for solutions and the growth of a neoconservative ideology almost regardless of party.

Having said this, it should be noted that there is very little evidence of a shift in mass support for welfare state programs. In 1982, well after the welfare state was supposed to be in trouble and well after the growth of the New Right, mass public opinion still supported core welfare state programs.

Philip Arthur AuClaire summarized data from representative national samples interviewed by the National Opinion Research Center between 1976 and 1982. ${ }^{12}$ Respondents were asked to indicate where government was spending too much. In 1982, well after the welfare state was supposed to be in trouble, there was actually a decrease in the proportion of respondents who thought we were spending too much on social welfare. (See Table 2.) There was a significant increase in the proportion who thought we were spending too much on military and defense.

The term "social welfare" is a global one and may carry negative images. Even though the trend indicated in Table 2 shows a decline, the absolute percentage calling for a cut is quite

12. "Public Attitudes toward Social Welfare Expenditures," Social Work, 29:139-45 (Mar.Apr. 1984). large. What happens if citizens are asked about their support of specific social welfare programs such as social security, Food Stamps, AFDC?

In the spring of 1983 the Detroit Area Study asked a sample of adults drawn from the Detroit metropolitan areanot just the inner city-their spending preferences for a number of specific programs. The preferences of this sample are very clear. They call for the expansion of expenditures on social security and the environment-less than 10 percent favor cuts in social security programs. Even programs such as AFDC and unemployment benefits fare better than national defense. In this respect, the American population's support of welfare state programs mirrors that found in Western European countries. $^{13}$

Although support for core programs remains firm, other aspects of federal growth have become suspect. There has been a growing disenchantment with the power and intrusiveness of the federal government. Such concerns may block support for the development of new programs. ${ }^{14}$

How can we sum up these trends in party attachments and issue alignments? There remains strong support for core welfare state programs. However, I conclude that there has been a weakening attachment to political parties and an increase in the volatility of the electorates. Voters split their choices more,

13. Richard M. Coughlin, Ideology, Public Opinion and Welfare Policy: Attitudes toward Taxing and Spending in Industrialized Societies (Berkeley, CA: Institute of International Spending, 1980).

14. Warren E. Miller, Arthur H. Miller, and Edward J. Schneider, American National Election Studies Data Sourcebook, 1952-78 (Cambridge, MA: Harvard University Press, 1980), p. 171. 
there has been a decrease in continuity from president to president-until Reagan, it had been 20 years since a president served two terms-and partisan attachments have clearly declined. Issue coherence has also declined. At the same time, there has been some party realignment, at least to the extent that some groups previously attached to the Democratic party are no longer so attached, and other groups, previously attached to the Republican party, have changed, sometimes slightly, their attachment. On domestic matters, at least, the Democratic party would appear to be more liberal than it was in the 1950s, because the southern Democrats who were conservative have now joined the Republican party. Yet, as I argue later, it may well be that even though the Democrats enjoy an edge in the so- called normal vote, the ability of the Republican party to mobilize the vote will give an edge to the Republicans in the years ahead.

\section{PARTY ORGANIZATIONAL STRENGTH, CANDIDATES, AND CAMPAIGNS}

The strength of parties has two dimensions: (1) the attachment of voters to parties; and (2) the internal organization and cohesion of parties so that parties and their leaders can deliver the vote-both on election day and, once politicians are elected, in legislative and executive action.

The decline of partisan attachment need not signal weak parties. As organizations, parties can be more or less strong, even if voters are more volatile in their voting behavior. Parties are organizationally strong if they can systemat-

TABLE 2

\section{RESPONDENTS WHO THOUGHT TOO MUCH WAS SPENT NATIONALLY IN SELECTED AREAS, 1976-82 (Percentage)}

\begin{tabular}{|c|c|c|c|c|c|c|}
\hline \multirow[b]{2}{*}{ Area } & \multirow{2}{*}{$\begin{array}{c}1976 \\
(N=1499)\end{array}$} & \multirow{2}{*}{$\begin{array}{c}1978 \\
(N=1532)\end{array}$} & \multirow{2}{*}{$\begin{array}{c}1980 \\
(N=1468)\end{array}$} & \multirow{2}{*}{$\begin{array}{c}1982 \\
(N=1506)\end{array}$} & \multicolumn{2}{|c|}{ Change* } \\
\hline & & & & & $1976-82$ & $1980-82$ \\
\hline Space exploration & 60 & 47 & 39 & 40 & -20 & +1 \\
\hline \multicolumn{7}{|l|}{ Protecting the } \\
\hline environment & 10 & 10 & 15 & 11 & +1 & -4 \\
\hline Improving health & 5 & 7 & 8 & 6 & +1 & -2 \\
\hline Assisting the cities & 19 & 19 & 21 & 19 & 0 & -2 \\
\hline \multicolumn{7}{|l|}{ Halting the rise } \\
\hline in crime & 8 & 6 & 6 & 5 & -3 & -1 \\
\hline \multicolumn{7}{|l|}{ Solving the drug } \\
\hline problem & 8 & 9 & 8 & 8 & 0 & 0 \\
\hline Improving education & 9 & 11 & 10 & 8 & -1 & -2 \\
\hline Assisting blacks & 25 & 25 & 24 & 20 & -5 & -4 \\
\hline Foreign aid & 75 & 67 & 70 & 72 & -3 & -2 \\
\hline \multicolumn{7}{|l|}{ Military and } \\
\hline defense & 27 & 22 & 11 & 31 & +4 & +20 \\
\hline Social welfare & 60 & 58 & 56 & 48 & -12 & -8 \\
\hline
\end{tabular}

SOURCE: Philip Arthur AuClaire, "Public Attitudes toward Social Welfare Expenditures." Copyright 1984, National Association of Social Workers, Inc. Reprinted with permission, from Social Work, Vol. 29, No. 2, March-April 1984, p. 140.

*A minus sign indicates a decrease in antispending sentiment; a plus sign an increase in antispending sentiment. 
ically mobilize resources to pursue the vote. They are strong and effective if they have the resources to pursue the vote and are able to deliver it.

One facile and common claim about American political parties is that their internal strength has significantly declined as their control of patronage resources has declined. Before civil service requirements became widely used in the hiring and retention of city and state employees, political parties were able to use the spoils of office to attract followers who also worked for the parties. Patronage, of course, included not only jobs, but city contracts and other benefits. The growth of civil service systems, competitive bidding requirements, and universalistic federal welfare systems has each disrupted a basis of party machine strength. The party machine as a source of welfare benefits has disappeared. Its ability to deliver a large number of lower-level jobs has been severely restricted, although a number of judicial and executive appointments are still politically made. Contracts are increasingly scrutinized by the press and are offered through competitive bidding. ${ }^{15}$

The last of the big city bosses who could deliver a city, a state, and an election was Mayor Daly of Chicago. And the last presidential election that was severely affected by a city machine was the Kennedy election of 1960.

The decline of the city machines might lead one to assume that party organizations at the state and local levels are weak. However, recent analysis suggests quite a different picture. James L. Gibson and colleagues have developed measures of party organizational strength at the state level. ${ }^{16}$ The measures included standard measures of organization or bureaucratic strength: number of organizational divisions, budgets, full-time personnel, research

15. James Q. Wilson, "The Economy of Patronage," Journal of Political Economy 69:369-80 (Aug. 1961).

16. James L. Gibson et al., "Assessing Party Organization Strength," American Journal of Political Science, 27(2): 193-222 (May 1983).

TAB LE 3

PUBLIC ATTITUDES TOWARD GOVERNMENT SPENDING ON FEDERALLY FINANCED PROGRAMS (Percentage of Respondents)

\begin{tabular}{|c|c|c|c|}
\hline \multirow[b]{2}{*}{ Program } & \multicolumn{3}{|c|}{ Attitudes on Government Spending } \\
\hline & $\begin{array}{c}\text { Should } \\
\text { spend more }\end{array}$ & Right amount & $\begin{array}{l}\text { Should } \\
\text { spend less }\end{array}$ \\
\hline \multicolumn{4}{|c|}{ Aid to Families with Dependent } \\
\hline Children & 29.1 & 50.6 & 20.2 \\
\hline Unemployment benefits & 30 & 57.7 & 15.2 \\
\hline National defense & 13.6 & 37.5 & 48.9 \\
\hline Social security & 52.1 & 41.5 & 6.4 \\
\hline Food stamps & 25.1 & 51.1 & 23.8 \\
\hline Industry loans & 27.9 & 53.5 & 18.6 \\
\hline Environment & 50.1 & 36.8 & 13.1 \\
\hline
\end{tabular}

SOURCE: Yeheskel Hasenfeld, "Public Attitudes toward the Welfare State" (Manuscript, Detroit Area Study, School of Social Work, University of Michigan, Spring 1983).

NOTE: Based on 550 respondents, Spring 1983. 
programs, fund-raising drives, newsletter publications, and so on.

Three conclusions emerge. First, at the state level, party organizations are stronger in 1975-80 than 1960-64. Second, both Democratic state units and Republican units are stronger overall. Third, however, there is marked regional variation, so that Democrats in the Northeast and Midwest actually appear to have weaker organizations as of 1980 than they had in the 1960 period, while those in the South and Southwest remain strong in 1980. Republicans in all regions appear to be stronger.

A series of in-depth reports by Thomas Edsal suggests that currently Republicans have an even larger advantage in their ability to raise money and in their organizational development. ${ }^{17}$ Although voters may be more volatile, and although Democrats still outnumber Republicans, it appears that in the 1980s Republicans are in a better position to use resources to mobilize the vote.

However, the increasing ability of state parties to staff organizations does not mean that parties can deliver votes; nor can mere Republican party strength cover for weak candidates. As Ladd and Hadley note, modern campaigns are increasingly candidate-, issue-, and media-oriented. ${ }^{18}$ Incumbent candidates win 87 percent of the elections they run in. Name recognition gives incumbents enormous leverage in congressional elections over challengers. And both Democratic and Republican incumbents are able to finance reelection campaigns through personal fund-raising organizations.

17. Washington Post, 6 and 7 June 1984.

18. Ladd and Hadley, Transformation of the American Party System.
State party organizations in the modern period have less to do with controlling incumbents than they do with financing campaigns in which challengers are promising and with encouraging strong challengers to run. In the modern era the state political machine is a facilitator of campaigns, rather than a controller of candidates. Jacobson and Kernell argue that in the late 1970s and in 1980 the Republicans were better at funding challengers and at channeling money to good challengers than were the Democrats. ${ }^{19}$ So, at least by the late 1970 s and early 1980s, the organizational advantage for supporting candidates belonged to the Republicans. Whether that is a long-range trend or not remains to be seen. The organizational techniques developed in the late 1970 s can be copied by the Democrats, though the Republicans may have a long-term advantage in that their constituencies have more discretionary income.

The growth of strong party organizations that help recruit candidates and provide campaign management skills has substantive implications for welfare-related programs. Although incumbents tend to win, in the modern age they are staying in office for shorter periods of time: there is more turnover. Since parties and party activists-on the Left or the Right - are more ideological than the voters, the growing role of parties in recruiting and funding candidates may lead to a more ideological and coherent set of candidates. If the advantage has swayed to Republican organizations, party consensus may be stronger against welfare-related legislation

19. Gary L. Jacobson and Samuel Kernell, Strategy and Choice in Congressional Elections (New Haven, CT: Yale University Press, 1981), p. 97. 
than public opinion. The Republican agenda is more likely to emphasize voluntaristic and local solutions to welfare state issues.

\section{PRESIDENTS, CONGRESS, AND PARTY CONTROL}

The changes in voter attachments and party organization are important, but there are other aspects of the ability of regimes to develop coherent policy. It could be argued that what is really important is the ability of Congress to concert on policy and the ability of the president to cajole and lead. Have there been changes in congressional organization and in presidential elections that have implications for the coherence and direction of welfare policy?

There certainly have been large changes in the way in which Congress conducts its business. For one, the 1960s saw the breakup of the southern-controlled seniority system in Congress. During the same time that the Republican party broke the Democratic stronghold in the South, northern congressional representatives acted to take power away from committee chairs and make comittee chairs more responsive to the membership. If the membership concerts in a given direction, it is in a position to have a larger impact today than earlier. ${ }^{20}$

Yet, other institutional processes may make it difficult to create consensus. The proliferation of staff and subcommittees creates multiple agendas. Eulau and McCluggage describe the proliferation of functions in Congress. ${ }^{21}$ The

20. Sundquist, Politics and Policy, pp. 512-23.

21. Heinz Eulau and Vera McCluggage, "Proliferation and the Institutional Structure of the Congressional Committee System," in The Challenge of Social Control: Citizenship and Institu- various components of the welfare state become parceled out over a larger number of subcommittees. Thus, in general, the combination of weak party control over incumbents, the rise of multiple jurisdictions and proliferation of staff functions, the decline of the seniority system, and the weakening of leadership control in Congress all contribute to making Congress a more difficult place to concert on policy initiatives. Only the possibility of a new ideological consensus among activists weighs in favor of concerted policymaking.

At the same time, the rise of the primary system deprives the state party of much of a role in presidential candidate selection. Although presidential candidates still must end up running on one party ticket or the other, they are relatively independent of party organizations. Jimmy Carter was more extreme in this than many presidential candidates, but it is a general rule of modern politics that winning presidential candidates - those who succeed in early primaries-gain media access and financial access relatively independently of party. Presidential candidates may work closely with state and national party leadership, but as a matter of choice more than of structured necessity.

So, both Congress and presidents are loosely linked to parties. Compared to those in Europe, parties in the American system have never been very well disciplined entities. Because of the separation of presidential and congressional elections-because state party machines are only loosely linked to national party organizations-they have never been

tion Building in Modern Society; Essays in Honor of Morris Janowitz ed. Gerald Suttles and Mayer N. Zald (Norwood, NJ: ABLEX, forthcoming). 
tightly disciplined in the model of parliamentary parties. Thus, strong consensus and party discipline or party cohesion is more likely only in times of crisis, and indeed then such unity is more likely when external crises emerge than when divisive national issues are on the agenda. Recent trends have exacerbated these tendencies toward fragmentation and proliferation.

A final item in this catalogue is the growth of pressure groups and singleissue politics. One characteristic of the modern period has been the ability of issue entrepreneurial groups to mobilize resources - for example, money, lobbying skills, and personnel-around very specific issues. Resource-mobilization theorists, such as McCarthy and Zald, have discussed the growth of professional movements and movement organizers. ${ }^{22}$ Jack Walker has documented the recent emergence of pressure groups less related to occupations and industries than early ones and funded by a variety of foundations, patrons, and sponsors. These new groups are interested in specific issues such as gun control, abortion, environment, marijuana law repeal, and automobile safety. ${ }^{23}$ Naderism is a national tendency!

The growth of single-issue politics increases the number of groups pressing for specific policy changes. Moreover, single-issue groups can have an impact disproportionate to their membership when they concentrate their resources on specific issues. Troyer and Markle have shown the powerful role of a

22. John D. McCarthy and Mayer N. Zald, The Trend of Social Movements in America: Professionalization and Resource Mobilization (Morristown, NJ: General Learning Press, 1973).

23. Jack L. Walker, "The Origins and Maintenance of Interest Groups in America," American Political Science Review, 77: 390-406(June 1983). professional movement organization in the battle against cigarette smoking. ${ }^{24}$ Single-issue constituencies and groups are not aligned with broad ideology or policies. Gais, Peterson, and Walker have described how the organization of the White House has shifted to providing linkages directly between issue constituencies and the executive branch. ${ }^{25}$ The consequence for politics is a great array of political issues unlinked to broader ideologies and visions of the state. Single-issue politics contributes to the diversity and lack of comprehensiveness of overall policy analysis.

The proliferation of subcommittees and single-issue groups leads to a sectoralization of welfare-related issues. Each area of welfare state policy has a separate set of constituencies. There are pressure groups, Congress members, and institutions in and out of government with interests in each subpolicy arena-some such arenas are children, child abuse, and child nutrition. When combined with the trends in the election of presidents and members of Congress, one sees a continual seething competition for space on the legislative agenda. Being on the agenda, however, is no guarantee of success.

\section{CORPORATISM, UNIONS, AND THE WELFARE STATE}

The analysis so far has dealt with trends in the formal structure of politics and government. We have examined trends in voting behavior, the legislative

24. Ronald J. Troyer and Gerald E. Markle, Cigarettes: The Battle over Smoking (New Brunswick, NJ: Rutgers University Press, 1983).

25. Thomas L. Gais, Mark A. Peterson, and Jack L. Walker, “Interest Groups, Iron Triangles, and Representation Institutions in American National Government," British Journal of Political Science, 14: 180-82 (Jan. 1984). 
and executive processes, and the growth of social movements and pressure groups. There is another aspect of political structure, at the same time more global and less partaking of the formal political apparatus, that deserves mention-the extent to which the co-optation of major groups and interests into the policy apparatus affects welfare choices and trends.

In recent years political scientists have examined the extent to which the major social groups in a nation-religious groups, occupations and professions, labor and management, institutions, and sectors such as education and health care - are hierarchically integrated and centrally coordinated. Groups and institutions are hierarchically integrated to the extent that locally dispersed units are bound by regional and national umbrella organizations. ${ }^{26}$ If, for instance, a national council of labor unions existed that on the one hand spoke for labor and, on the other hand, was accepted as an authoritative body by union officials, we would speak of a hierarchically integrated union structure. Or similarly, to the extent that we had a national teachers union that spoke for teachers in local areas, was responsible to a central ministry of education, and made demands on that central ministry, we would speak of a hierarchically integrated educational system. The central coordinating role depends upon the extent to which other units in the nation recognize the power and role of the national representative organizations. For instance, if unions were hierarchically integrated and bargained on labor policy in conjunction with peak em-

26. Philippe C. Schmitter and Gerhard Lehmbruch, Trends toward Corporatist Intermediation, Contemporary Political Sociology, vol. 1 (Beverly Hills, CA: Sage, 1979). ployer groups and government officials, labor-management relationships would be described as corporatist.

At least theoretically, corporatism can exist with or without competitive elections and democratic politics. Italy, in the time of Mussolini, is given as an example of a corporatist polity without democracy. On the other hand, Sweden today is a corporatist, yet democratic, state. Corporatism also can be said to exist in one-party states, such as Mexico, as long as major groups are represented and integrated in the decision structure.

Most relevant here, where corporatism includes strong labor unions and strong social-democratic parties, the welfare state becomes well entrenched even in periods of retrenchments and recession. A relevant contrast is between Japan and Sweden. Both are corporatist, but Japan's labor unions are dominated and do not represent a significant group in setting state policy. In a sense, Japan can be considered a case of incomplete corporatism; industry is tightly integrated with government, but labor representation is weak at the policymaking level.

Where does the United States fit in such a picture of state policymaking? It is clear that the United States is far from a corporate state. First, labor and management are neither hierarchically organized nor coordinated. Although national groups, such as the American Federation of Labor-Congress of Industrial Organizations (AFL-CIO) and the U.S. Chamber of Commerce are peak organizations, they do not include all relevant industries and unions, nor do they control their members. There is some industrywide bargaining between labor and management, but little peak bargaining in which government poli- 
cies are directly affected. Labor and management in some industries will concert to make representations to government officials; they will lobby for the same thing-for instance, higher customs duties, or exclusion of foreign automobiles or foreign steel-but they do not work hand in hand on a regular basis with government committees and administrators. Moreover, at the level above single industries there is little coordination among industry groups and little integration across groups, whether they be labor and management, education, health providers, or health unions.

Second, because of the decentralized structure of the political system, many institutional sectors have a very weak voice and do not operate much at the national level. Teachers unions, for instance, bargain on a one-on-one basis either at the state level or, more usually, at the school-board level. Hospital unions bargain with individual hospitals or occasionally with citywide bargaining associations.

Third, the oscillation of parties and the weak connection of labor to parties mean that labor's voice in the national scene has always been weak compared to the social-democratic leftist parties in Europe. Although labor and labor unions have historic ties to the Democratic party, they do not control party policy. Moreover, many workers and unions do not support the Democratic ticket, and when a Democratic candidate wins a presidential election, labor cannot count on strong access to the White House.

Given the extent to which corporatism is in fact very unlikely in the American context, the important issue becomes the extent to which the union movement-which has always been a major supporter of welfare state policies, though sometimes a supporter of welfare policies more important for its members than for the poor in generalwill become more powerful. But, of course, it is clear that the union movement is declining in power and, at least over the last decade and a half, has had a declining political role. Moreover, the key growth areas in the United Statesservice industries and high technologyare the areas in which unions have traditionally had the most difficulty making inroads.

It would, of course, be a mistake to assume that all unions are in a period of retrenchment just because, for instance, the automobile workers and steelworkers are losing members. It would also be a mistake to assume that specific unions are not able to exercise real power and clout in areas of direct concern to them and their members. However, any possibility of strong unions to mount a systematic drive for expansion of major welfare state programs would seem to be unlikely. The weakness of unions in the most recent period is at least in part a function of the ability of corporate capitalism to move and invest in other countries. The ability of management to move capital internationally becomes part of the process by which union protection of jobs is broken down. Since unions in America have little control over capital flows, unions in this period have to fight rearguard actions. One direction possible for the welfare state in the future does involve corporatist solutions, for new blueprints calling for a national industrial policy often require the integration of labor, management, and government. Nevertheless, current trends in union strength and union organization suggest greater, rather than less, control of investment deci- 
sions by management. Unions have little ability to act as the bellwether of the welfare state.

\section{CITIZENSHIP RIGHTS AND ENTITLEMENTS}

The growth of the welfare state occurred not only through the development of new programs for reaching out to dependent populations, but also in the establishment of the rights of citizens to the program benefits. In nations in which the welfare state has become institutionalized these rights have been tested in courts and treated as beyond arbitrary bureaucratic intervention. What has happened in the United States in the area of citizenship rights? What rules regulating government provision of services have been developed both through enacted law and through court adjudication? Especially in the American case, with its strong separation of powers and the strong role of the judiciary, any account of the welfare state must ask to what extent have goods, services, and liberties become entitlements-rights no longer dependent on the arbitrary disposition of officials. ${ }^{27}$

T. H. Marshall, a distinguished British sociologist, divided citizenship rights into civil, political, and social. ${ }^{28}$ Civil rights included freedom of contract, movement, and disposal of one's labor.

27. For a view from the Left of the process by which privileges and gifts are transformed into citizenship entitlements, see Rand E. Rosenblatt, "Legal Entitlements and Welfare Benefits," in The Politics of Law: A Progressive Critique, ed. David Kairys (New York: Pantheon, 1982), pp. 262-80. For a conservative view of the process, see Jeremy Rabkin, "The Judiciary in the Administrative State," Public Interest, 71: 62-84 (Spring 1983).

28. T. H. Marshall, Class, Citizenship, and Social Development (Garden City, NY: Doubleday, Anchor Books, 1965), pp. 78-91.
Political rights included voting, office holding, and political expression. Social rights included access to economic goods and services to maintain a tolerable level of living, health care, access to education, and appropriate social inclusion. Marshall was concerned with citizenship rights beyond the political and economic; social inclusion, the ability to participate in the community, was also an emerging right. For Marshall, civil rights came first, then political rights, and finally social rights. Rights may be constitutionally guaranteed or, as in many European countries, they may be strong legislative commitments in which the unwritten constitution provides the guarantee.

What can be said about the extension of rights in relation to the welfare state in America? There would appear to be four main trends. First, as the federalization of programs occurred and as federal courts adjudicated claims, citizen access changed from discretionary privileges granted by agencies to rights. As developed through a long line of cases, welfare benefits no longer were to be treated as gifts or benefices; rather, they were a new form of property. Once the government sets up a park for public access, or a welfare program, it no longer can choose which citizens have access to those programs unless the criterion of choice has a direct relationship to that program. For example, people cannot be excluded from public parks because of the way they dress; the reason for excluding persons from AFDC must deal with their family composition and income, not their race, religion, or political views. In other words, public programs, once enacted, are available to all citizens for whom the original legislation was intended, without further discrimination or rights of 
discretion on the part of officials. Universal entitlements occur in fully federalized programs. But even programs such as Medicaid and AFDC, in which some discretion in matching moneys or in levels of benefits have been left to the states, have had strong controls placed upon the ability of the participating states to exclude groups or individuals.

Second, civil rights have been extended to welfare state beneficiaries, or dependents. The imprisoned or institutionalized dependent population-mental patients, prisoners - have rights of expression, freedom of religion, some freedom of communication, and access to the courts, as do other citizens. It is no longer the case that hospitalization or imprisonment deprives citizens of many of their civil rights, except freedom of movement.

Third, the extension of entitlements has been accompanied by the judicialization of procedures. Now citizens have a right to proper notice of administrators' decisions on allocation of benefits to entitlement programs as well as a right to appeal those decisions. This means that the AFDC applicant has the rights of notification and of appeal, as does the social security applicant. The right of appeal, of course, is a way of limiting administrators' discretion.

Finally, there has been a trend, possibly now arrested, in which the courts mandate the level of welfare benefits. The unfinished story of social rights in the welfare state concerns the extent to which the courts are willing to assert what level of benefits the state must provide if it is providing a public program of some kind. One of the most famous court decisions was that of Wyatt v. Stickney. In that Alabama case, Judge Johnson of the federal district court ordered Alabama to raise massively its level of provision of services for people in state mental institutions. The case of Wyatt v. Stickney follows in a legal tradition in which the courts have moved, on the one hand, to limit involuntary incarceration to mental hospitals in order to make it more difficult for the state to put people in institutions without their consent, and, on the other, to establish standards for what levels of care or treatment must be provided, once incarceration has occurred. The issue in these cases, especially when generalized to other areas, involves the extent to which the state must provide professionally responsible levels of care, adequate levels of education, adequate rehabilitation, professionally mandated levels of care to the physically handicapped, and so on.

An activist/expansionist view of the matter is that judges are protectors of individual rights, and, much as they do in bankruptcy proceedings in which the courts protect the claims of shareholders and others with property rights, they should move to protect the substantive rights of citizens. Rights become defined in terms of an expanded view of citizen entitlements. On the other hand, a restrictive view is that citizen entitlements are, in the welfare arena at least, largely legislative matters in which judges may intrude only with great risk of upsetting representative, majoritarian government. By now it would appear that the tendencies for court usurpation, or extension of power to the setting of benefit levels, have been arrested. The Burger Supreme Court has made few moves to intrude on procedural rights, the civil rights of inmates, or the universalistic administration of programs.

On ideological grounds, one would assume that a Supreme Court with an increasingly conservative cast would be 
loath to expand substantive entitlements. Yet court decisions and processes are only loosely tied to immediate political trends and prior ideological expressions. In a situation in which legislatures at the state and federal levels often enact laws with broad social goals but with ambiguous boundaries, it is likely that the courts will continue to play a role in the definition of substantive entitlements. ${ }^{29}$

\section{THE WELFARE STATE AND EQUALITY: IMPLICATIONS OF POLITICAL TRENDS}

There are several implications for welfare policy and outcomes suggested by this analysis. First, the fragmentation of the system and the inability of congressional leaders to control members suggest that many major crises or problems of the welfare state will be difficult to handle through normal political channels. A good example is found in the search for solutions to the shortterm social security crisis that led to the 1981 amendments to the Social Security Act. ${ }^{30}$ The inability of Congress and the president to concert finally led President Reagan to establish a commission that brought together significant parties outside of normal congressional processes. Only through a process that brought in all of the major lobbying groups and all of the major figures in a kind of crisis corporative solution was it possible to enact amendments.

A second implication of our analysis is that fragmented policymaking is likely to be the rule. Comprehensive, or even quasi-comprehensive, policy change

29. This argument follows that of Theodore $\mathbf{J}$. Lowi, The End of Liberalism (New York: W. W. Norton, 1969).

30. See Birdsall and Hankins, "Future of Social Security." that is bargained out between major groups and major policy changes that are enacted through the involvement of several different sectors are increasingly difficult to achieve. On the other hand, single-issue changes will occur. The 1984 changes in reimbursement formulas for hospitals are an example. They signal changes in the economics of health care. And, as Garfinkel shows, small changes in administrative procedures can have a large impact on specific policies. ${ }^{31}$

Unfortunately, many of the groups for whom welfare state policies have deep implications are not themselves able to mobilize forces for change. For instance, teenage unemployment is now near all-time highs. It is ironic that one of the major groups trying to change policies that affect teenage employment are the fast-food chains and their lobbyists. Here, where minimum-wage laws impede the ability to get cheap inexpensive labor, we see a single-issue political strategy used that may have positive benefits for teenagers but that is the political province of a different group altogether.

But what of the implications of these political trends for the larger issues of welfare state politics? The larger issues have to do with (1) the impact of welfare policy on equality; and (2) the impact of welfare state policy on universal access.

First, it is clear that the retrenchment processes we have seen in the late 1970s and 1980s have not led to the elimination of major welfare state programs. In the areas of unemployment insurance, social security, and health care, programs have been retained and even expanded. For instance, the unemploy-

31. See Irwin Garfinkel, "The Role of Child Support Insurance in Antipoverty Policy," this issue of The Annals of the American Academy of Political and Social Science. 
ment compensation system was changed to expand the length of time people could be eligible for unemployment insurance, as the percentage of the population that was unemployed increased. But in other areas, such as medical care financing and social security, an attempt has been made to rein in the benefits of the welfare state. It is difficult to say whether these cuts have increased inequality because the cuts impact on such a large part of the population. On the other hand, programs such as Food Stamps and AFDC, which are targeted quite directly on the poor and especially the younger poor, have been cut or the rate of increase controlled, and in these areas the trends in the welfare state suggest that very dependent populations with little political clout will become even less equal in the future.

The other implication of this analysis has to do with the universality of programs. The attempt to rein in the welfare state and the attempt to become cost efficient have led to a great focus upon third-party payments, upon incentive systems for people to take care of themselves by increasing private pension programs and the like. Corporations may choose to provide child-care programs as a fringe benefit to attract working wives. That benefit becomes a business expense and also decreases the profit and corporate taxes paid by corporations. In general, over the next several decades, we suspect that the political trends, the slight conservative drift, and the disillusionment with the welfare state will all lead to solutions in which services are less universally provided. Core welfare state programs may be protected, but marginal social services and benefits are more likely to go to the protected sectors and more middle-class sectors than they are to be widely expanded on a universal basis. 